\title{
Congestion Charging: Challenges to Meet the UK Policy Objectives
}

\author{
PHILIP T. BLYTHE* \\ Transport Operations Research Group, University of Newcastle upon Tyne
}

\begin{abstract}
This paper reviews and comment on the current issues of road-use charging in the UK from two perspectives, the technical and the political. The paper concludes that the lack of appropriate technology will not be the constraint in implementing road-use charging in the near future in the UK, and new technologies that are currently being researched should not be excluded as possible future solutions for charging. However the local authority schemes that are now up and running in London and Durham, the on-going National Trials in Leeds, the policy of introducing distancebased charging for Heavy Goods Vehicles and the Commission for Integrated Transport's proposal to have distance-charging black-boxes in all UK registered vehicles suggests certain policy divergence which may be difficult to "sell" to the public.
\end{abstract}

\section{Introduction}

The argument for the introduction of a charge that reflects the real use made by an individual of the road network is not new. It is argued that this would be a useful tool in improving the efficiency of allocating a scarce resource between competing users and thus reflect better the real costs of using the road, namely the marginal social cost. Most users do not make the connection between their perceived costs of using the road (fuel costs, vehicle wear and tear and vehicle excise duty) to the real costs which include the social costs to the environment, wear and tear of the road infrastructure, and the users contribution to congestion and the associated costs that are imposed on other road users due to that congestion. Although surveys of attitudes about road use and congestion have consistently highlighted concerns with traffic congestion for at least 25 years now, in the UK until recently such an argument fell on deaf ears due to political reluctance and the usual I accept there is a problem but NIMBY (not in my back yard!). However, since 1998 there has been a fundamental change in attitudes regarding how the UK government and some local authorities view the problem. We need to take a retrospective look at UK road transport over the past four decades to understand how we have arrived at this point.

\footnotetext{
* Professor of Intelligent Transport Systems, Director: Transport Operations Research Group, Cassie Building, University of Newcastle upon Tyne, UK, NE1 7RU, Tel +44 191-222-7935, Fax +44-191-2228352. Email: p.t.blythe@ncl.ac.uk The author wish to thank the following persons for their advice and support in the preparation of this paper: Dr John Walker, Thales Translink; Mr Paul Knight, Faber Maunsell; and Dr Alan Tully, Computing Science, Newcastle University.
} 


\section{Overview}

The milestone government report "Traffic in Towns", better known as the Buchanan Report (Buchanan, 1963), predicted that the 12 cars owned per 100 people in 1962 would rise to 38 cars per 100 people in 1995. They were right; and this heroic prediction underscores all the problems to which the relentless growth of car ownership has produced over those three decades. Where the authors of the Buchanan Report were wrong in their prediction, however, was in assuming little further growth beyond that. They predicted that a "saturation" level in ownership would be at only 40-45 cars per 100 people by about 2010. The truth is that saturation ownership levels already being reached in several countries (USA, Italy and Luxemburg, for example) are at 60-65 cars per 100 people. This and other evidence points to the UK being still only two-thirds of the way to saturation level in car-ownership. If real disposable incomes continue to rise, the overall size of the car population in the UK is likely to rise, from $23 \mathrm{M}$ this year to an eventual plateau of $33 \mathrm{M}$ to 36M some time before 2040 (Department for Transport, 2003).

If we choose not to plan for it or fail in our best endeavours to combat it, a prospective $50 \%$ increase in traffic over the next 30 or so years will lead to a considerable worsening of congestion. It has been estimated that the overall cost of traffic congestion to the UK as being in excess of $£ 21,000 \mathrm{M}$ per year (Blythe, 2003). This is more than all the other "external" costs of road traffic that fall on society (accidents, noise, pollution, $\mathrm{CO}_{2}$ output, etc.) put together. The potential economic returns and social benefits of reducing congestion, therefore, are huge.

In the 1998 White Paper (Department for Transport, 1998) a shift in emphasis in transport policy was made, moving away from the short-term "predict and provide" policy of building roads to meet demand to the emphasis on "Integrated Transport" and utilising policy and ITS-tools to persuade the UK's drivers to "use their cars a little less and use alternative transport a little more". Key to this was the promise of enabling legislation to make possible for local authorities to introduce congestion charging, as a means to manage traffic congestion and to allow local authorities to retain the income for re-investment in the local transport infrastructure and improvements in public transport. This has resulted in a number of cities adopting or proposing to adopt road use charging using a variety of technological solutions.

In parallel with this, the Department for Transport launched the DIRECTS (Demonstration of Interoperable Road-user End-to-end Charging and Telematics Systems) research programme which aims at developing interoperable solutions for road use charging in Leeds with a view to delivering a National Specification for congestion charging (Mackinnon 2003, Tindall 2004). The trial phase, with around 800 volunteer drivers will be launched in late 2004 .

The two activities above make a sensibly synergetic package - however for road-use charging in the UK, this is not the full story. The successful fuel tax protests of 2000 posed a problem for the government in dealing with the increasing inflows of foreign Heavy Goods Vehicles haulers that fill up at Irish and continental Channel ports with their (now cheaper) diesel and use the British road network "for free". This in turn led the Treasury in November 2001 (HM Treasury, 2001) to publish a consultation paper on distance-based charging for all Heavy Goods Vehicles, British and foreign alike, to ensure fair competition in haulage and shift to an efficient direct charging regime "at the point of use". The precedent for this already exists: Switzerland and Austria have already introduced 
nationwide charging schemes for Heavy Goods Vehicles since 2000 and 2004 respectively (Balmer, 2003) and Germany plans to in 2005 (Charpentier and Fremont, 2003; Ruidisch, 2003; and Kossak, 2004). The Chancellor (that is, UK Finance Minister) confirmed plans for distance-based Heavy Goods Vehicles charging in his April 2002 budget that has the backing of the Freight Transport Association (FTA) and of the Confederation of British Industry (CBI). The launch of the procurement phase was made in May 2004 with the current timetables that suggest the Heavy Goods Vehicles charging will be introduced in the UK in 2008 (already a slippage of 2 years from the originally mooted launch date of 2006). In the background, however, there is the feeling that the real agenda is to examine the feasibility of how quickly such a scheme can be "rolled out" to include cars and other vehicles using our congested motorways, that is a National Road Use Charging Scheme. The Commission for Integrated Transport sees this as the logical corollary to developing congestion charging in the urban "hot spots" (Commission for Integrated Transport, 2002) and this future approach was largely confirmed in a major policy speech by the Secretary of State for Transport on $10^{\text {th }}$ July 2003, who announced a major research programme to examine all aspects of such an approach (Times, 2003).

The paper will consider how these competing initiatives for road-use charging in the UK are evolving, how technical and interoperable convergence may be possible in the future and what impact charging may have on future transport policy in the UK. This is not a new issue; the technology for electronic road pricing has been debated ever since the trials of ERP were hosted in Hong Kong as far back as 1985. Some of the most visionary and ground-breaking research was led by the late Professor Peter Hills' team in Transport Operations Research Group (TORG) at Newcastle University (Hills and Blythe, 1989; and 1990).

\section{$3 \quad$ Making the case for traffic restraint}

One of the direct consequences of rising car-ownership and use is the steady year-onyear decline in patronage for most forms of public transport. Across the country, outside of Greater London, the overall person-kms of bus-use have been declining relentlessly since the early $1960 \mathrm{~s}$, at between $-2.0 \%$ and $-4.0 \%$ per year, as passengers opt out of bus-use in favour of the strongly perceived advantages of going by car (figure 1).

The Conservative government of the early 1980s mistakenly regarded the inability of public transport operators to retain their market share as being due to lack of competition and to excessive regulation. The Transport Act 1985, therefore, set about the deregulation and privatisation of all bus operations outside Greater London. Although much was achieved by this radical shake-up (the breaking of union power, sharp reductions in real costs of bus operation, the widespread introduction of minibuses, downward pressure on wage-levels, some reduction in overall subsidies for public transport and so on), the one key indicator it failed to influence was the on-going year-on-year loss of patronage. In the English Metropolitan Counties, the privatised bus operators have lost more than $40 \%$ of their person-kms over the 17 years since deregulation. The irony is that Greater London, the only place in Great Britain exempt from the 1985 Act, has managed to hold on to its patronage and, in recent years even to increase it. London, of course, is unique in its size, its chronic traffic congestion and its comprehensive railway network, encouraging very high levels of public transport use, especially for journeys to work in the centre. 


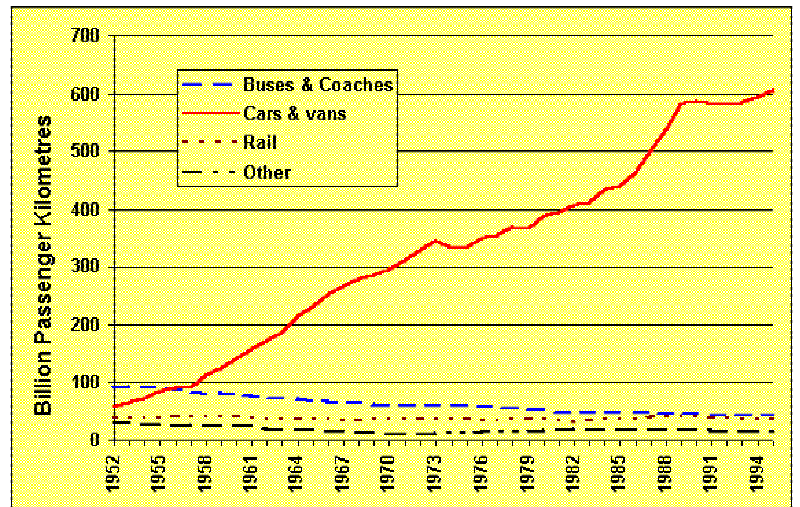

\section{Figure 1: Passenger travel by mode 1952-1995 Great Britain}

Note: in "Developing an integrated transport policy: Factual background" August 1997, Government Statistical Service.

All of this suggests that the scope for public transport to compete successfully against cars, so as to curb the future growth of traffic, is severely limited (particularly in the deregulated environment we now have). It would require authorities with powers similar to those of Transport for London to be set up in all metropolitan areas or regions in Britain, to enforce Quality Contracts with private operators, to plan new public transport investment, and to administer increasing volumes of public subsidy in order to stabilise the market share.

In any other sector, faced with a rapidly rising demand, the most obvious response usually is to expand supply to keep pace. This would be possible in the case of road traffic, except in the larger urban areas, but is no longer regarded as an acceptable solution in isolation. On interurban trunk roads and motorways, capacity can and will be provided mainly by widening the congested sections of the network rather than by building new routes in green fields. However, in suburban areas, where car-ownership and use is rising fastest, the opposition to new road building is considerable. Often, the argument revolves around the question of "induced" traffic, that is that building new roads, by adding capacity to the network, induces more traffic than before. Although the Standing Advisory Committee on Trunk Road Assessment confirmed in their report (SACTRA, 1994) that this was a real phenomenon and should be accounted for in highway planning and evaluation, it is usually only at the level of a side effect. Indeed, except when the amount of induced traffic is sufficiently large to cause congestion on the new road, it will generally contribute to the economic benefit of the scheme. The National Road Traffic Forecast (NRTF, 1997) confirmed this, by demonstrating that, in the long term, even if no more road capacity were built, future traffic would be "suppressed" by only $10 \%-12 \%$ due to increasing congestion. The economic cost of this mounting congestion, of course, would be huge.

The third approach often canvassed is one that invokes planning policies aimed deliberately at reducing the need for travel and the perceived dependence on cars to provide it. Advocates of this approach argue that residential densities should be increased sharply, new developments concentrated on "brown field" rather than "green field" sites and in corridors amply served by public transport. Much tighter parking standards and 
persistent campaigns to change people's lifestyles in favour of bicycling, walking and (if necessary) car-sharing are all part of this approach. Unfortunately, apart from a few wellpublicised successes, so much of this goes against the direction of current market forces in planning and development that it is hard to see how this will be effective in curbing overall traffic growth, even in the long-term.

The remarkable features of the 1998 White Paper (Department for Transport, 1998), and of the Transport Act 2000 to which it gave rise, are threefold: first, that it recognised for the first time, at government level, that traffic restraint policies are inevitable ("demand management" is the euphemism employed). Secondly, that no single approach to the problem of future traffic growth will be effective on its own, hence the emphasis on "integration" and multi-modal studies. Lastly, and most crucially, it introduced the possibility of including congestion pricing as the one part of the "integrated package" of policies that has the necessary potency to curb traffic growth.

\section{$4 \quad$ Moving towards pay as you go}

The easiest way, administratively, to raise the overall "price" of car-use is for government to increase fuel duty on the price of fuel at the pumps. This is being done in relative terms by reducing the annual fixed-charge vehicle excise duty; for example, fuel tax for a 38tonne (4x2alxle) lorry has increased from $83 \%$ of annual taxes in 1998 to $93 \%$ in 2003 (McKinnon 2004), making the taxes more closely reflect the distance travelled. The Royal Commission on Environmental Pollution (RCEP) in 1993 - having largely dismissed the arguments for congestion charging - proposed the doubling of retail fuel prices in real terms within 10 years. On the strength of this advice, the (then) Conservative government introduced the ill-starred fuel-price "escalator", at $+5 \%$ per annum in real terms, "for the foreseeable future". In the run-up to the 1997 election, New Labour were not to be outdone and promised to raise this to $+6 \%$ per annum! By Autumn 2000, when the whole policy unravelled in the face of blockades and civil protests, the retail price per litre of petrol in the UK was the highest in the EU.

Even without the spontaneous revolt, the arguments against continuing the escalator were compelling. Although fuel tax is paid proportionately to the use made of the roadsystem, it makes no distinction between that use being on a rural road at night and on a city centre street at the peak of the morning journey-to-work rush. In short, fuel taxes are a poor proxy for the marginal costs of congestion. Nevertheless, the political set-back of the successful fuel tax protest posed a problem for the government in dealing with the increasing inflows of foreign Heavy Goods Vehicles haulers, filling up at Irish and continental Channel ports with their (now cheaper) diesel and using the British road network "for free".

To bring about the "pay as you go" policies outlined above, technically, we need to introduce an efficient charging mechanism that can levy road-use charges automatically from drivers without the need for them to stop and pay. Thus, charging systems should enable the collection of these charges at normal highway speeds and without the need for segregating vehicles into separate lanes, as with conventional toll-collection facilities. Indeed, it would be infeasible and unworkable, in many locations, to require traffic to be segregated into lanes, drivers to stop their vehicles and pay cash to an operator or by inserting coins, bank-notes or a card into a collecting machine. Building these toll plazas 
(such as those at the Dartford, Tyne, and Mersey river crossings and throughout Southern and Central Europe, where purpose-built toll roads are widespread) is costly and crucially requires substantial land-area for each site. It is generally not practical to "retro-fit" a toll plaza to an existing road - in urban areas, this may be unacceptable on other grounds also such as the creation of additional congestion, noise and air pollution. Moreover, purposebuilt toll roads have a limited number of entry and exit points, whilst access to un-tolled roads usually is not so restricted - creating an additional difficulty when introducing urban road charging.

The publication of the Government's White Paper in 1998 (Department for Transport, 1998) caused a shift in emphasis in the UK away from road building, based upon the "predict and provide" principle, towards demand management (that is traffic restraint) and a better integration of modes. Moreover, to encourage Local Authorities to consider congestion charging as an option to manage the demand for car travel, the Transport Act 2000 requires Local Authorities to retain the net revenue raised from congestion charging and/or private non-residential (PNR) charging for a minimum of 10 years - to be reinvested in local transport schemes including public transport. This provision may well be the lynch-pin in cities being able to secure sufficient public acceptance for future congestion charging schemes, offering a mechanism whereby the "stick" of Congestion Charging can be offset by the "carrots" of a new revenue stream to finance improvements in local transport and infrastructure.

The concept of direct road-use charging is not new. Indeed, road-use charging has been considered as a tool for managing congestion and raising revenue for many decades, although few trials and implementations have actually taken place. The economic theory on which the principle of road-use pricing is based was put forward by Pigou (1920), with Vickrey (1969) and Walters (1961) relating it specifically to road traffic. The first "official" acknowledgement of the technical possibilities of direct pricing at the point of use was the Smeed Report (Smeed, 1964). Since then, a great deal of research has been undertaken and a number of attempts to introduce urban road-use charging have been made, most notably the Hong Kong trials (1983-85 and 1998), the Singapore Area Licensing Scheme (1975-1998) - now replaced by an automatic electronic scheme ${ }^{1}$ - and the toll-rings around Bergen, Trondheim, and Oslo in Norway (Blythe et al, 2001). Motorway schemes, using electronic devices to automate existing toll-collection facilities are quite widespread and include numerous examples in the USA and in the ASECAP explain the acronym and give references countries (Italy, France, Greece, Spain, Portugal), as well as new multi-lane tolling schemes on Toronto's Highway $407^{2}$ and the Melbourne CityLink $^{3}$.

\section{$5 \quad$ Technical options for delivery a charging policy}

Currently, several electronic technologies are used or have been considered for charging. The more important of these are briefly reviewed below.

\footnotetext{
${ }^{1}$ See http://www.lta.gov.sg

${ }^{2}$ See http://www.407etr.com

${ }^{3}$ See http://www.transurban.com.au/
} 
- Dedicated Short-Range Communications (DSRC) systems, for two-way communication between a roadside or gantry beacon and in-vehicle tags or transponders.

- Wide Area Communications-based systems, which use some form of location system coupled with communication systems to manage and enforce the charging.

- Video-based License-Plate Recognition systems, using roadside cameras with automatic optical character recognition (OCR) software to match vehicles' number plates with a pre-registered list.

\subsection{Microwave-based dedicated short range communication (DSRC) systems}

These systems need roadside equipment, typically mounted on a gantry, with electronic transponders in the vehicle. These transponders enter dialogue with a gantry-mounted antenna, and a transaction is automatically made between the roadside and the vehicle. If the transaction is successful then the driver is informed in some way, if not then the vehicle licence plate is recorded for enforcement purposes. At present DSRC is the most common form of road user charging and tolling, however such systems require each vehicle to be equipped and for some form of roadside infrastructure to be installed at each desired charging point (which can be quite intrusive when a free flow multi-lane charging configuration is required - as would be the case for most locations in the UK).

A modular approach is adapted to the transponder's design, facilitating "add-on" peripheral equipment (for example smartcard readers, keyboards, displays, connections to other in-vehicle equipment). Such transponders were first developed in the EU funded project ADEPT (automatic debiting and electronic payment for transport) project in the early 1990's (Blythe and Hills, 1994; and Blythe 1998), a European funded project led by TORG in the early 1990s which installed trial systems in Cambridge (UK), Sweden, Portugal and Greece. The modularity in the design of the automatic debiting transponder prototypes allows several different forms of payment (all of them "cashless") with one device. Possession of a transponder offers uses the possibility of holding a positive (or a limited negative) balance of credit-units, either directly in the transponder's memory or alternatively on a separate smartcard interfaced to the transponder. The smartcard, being portable, can then be used for other payment purposes and provide the link to public transport ticketing too.

These systems are perceived by many international road administrations as the future of road-use charging, where high-volume, multi-lane roads need to be tolled without restricting traffic flow. Europe standardisation of DSRC systems nears completion and many products based upon $5.8 \mathrm{GHz}$ microwave communications technology will soon emerge, though to date few commercial installations exist. Worldwide, the Singapore system and Highway 407 in Canada utilise such an approach. The DIRECTS project, using 800 or so volunteer drivers who will have their vehicles equipped for the trial in Leeds, will finally prove an end-to-end solution for DSRC-based charging. The aim of UK Department for Transport is to develop a national specification for interoperable payment of road-use charges, consistent with the emerging European standards. 


\subsection{Wide area communications-based systems}

Wide-area systems are a more recent innovation in charging and tolling technology - also widely known by the term MPS (mobile positioning systems). They use two technologies adapted from other applications; namely, GPS (global positioning system), whose satellites enable suitably equipped vehicles to calculate their location accurately; and a two-way communications link to confirm the in-vehicle unit is switched on and working, to update digital maps and tariff charges and for enforcement purpose (usually this link is either a cellular phone link or uses DSRC). Such systems were first tested in the German trials on the A555 Koln-Bonn autobahn in 1995-96 in parallel with an EPSRC-funded trial in Newcastle during the same period and a little later in Hong Kong 1998-99 (Blythe, 1999). They are designed (like DSRC systems) not to disrupt the flow of multi-lane traffic on motorways. Moreover, because in urban areas "virtual" toll-points can be established (and changed, as necessary), these wide-area systems will reduce the amount of environmental intrusion caused the by roadside infrastructure required (as this is only required for enforcement points rather than at each charging location), in comparison to DSRC systems.

GPS-Based wide area systems. The in-vehicle unit (IVU) contains a GPS receiver and a processor which contains a digital map and map matching software which contains either a fixed or an updatable record of the locations of all charging points or roads upon which a charge is to be levied. When the IVU determines that the vehicle is about to pass a charging point or to enter a road on which distance-based charging is to be implemented the system will warn the driver and once past the charging threshold, road user charges will be levied - these transactions are logged by the in-vehicle unit. At specific points (in the case of DSRC communications) or at specific times (in the case of GSM) the in-vehicle unit is communicated with and the record of charges levied are communicated to some central clearing system. Enforcement is generally configured in a similar way to the DSRC option, however in Germany, roving "enforcement vehicles" are proposed to enforce their proposed HGV charging scheme. Such a solution lends itself to distance-based and zonebased charging as well (Charpentier and Fremont, 2003; Ruidisch, 2003; and Kossak, 2004).

Third generation cellular radio technology Proposals have been made for tolling systems based on charging for entering a radio "cell", with the first trials being held on the A555 Köln-Bonn autobahn in 1996 using standard GSM. Trial with 2.5G (namely GPRS) have not shown any significant progress with the localisation of the in-vehicle unit to any degree of accuracy which could deliver a credible system for road user charging at the moment. Indeed the use of Cell Ids as a means of automatically locating the position of the phone handset have recently been tested in the built up urban area of London with extremely poor results. However, this may change with the potential locationing function that will be inherent in the third generation $(3 \mathrm{G})$ licences for mobile phones. The $3 \mathrm{G}$ companies claim an accurate location service for business phone users - perhaps down to 10-15 metres resolution - which is ample for road-use charging purposes (although evidence for enforcement and prosecution may require a greater accuracy in the proof of location). However experience with current versions of $3 \mathrm{G}$ phones in tests in Newcastle and the extensive trials undertaken by TfL (Transport for London) in London in the first six months of 2004, to evaluate potential future technologies for an extension to the London Congestion Charging scheme suggest that location accuracy is in the region of several $100 \mathrm{~m}$ at best (Evans, 2004). Nevertheless, as mobile phones are owned by a 
significant proportion of the population and have secure access and a central payment facility (as well as pan-European interoperability) they should not yet be discounted out of hand as a possible future charging technology (Birle, 2004).

\subsection{Video-based license-plate recognition}

Video-based systems Video-based systems rely on the accurate "reading" of vehicles" licence plates as the primary means of identifying, charging and enforcing vehicles in a congestion charging scheme. Automatic number plate recognition (ANPR) systems process the video images taken by a camera at the roadside or on a gantry, locate the number plate in the image and convert this into the appropriate alphabetic/numeric characters, without any human intervention. The big advantage is that it removes the need for any in-vehicle equipment. Moreover, it solves the "occasional user" problem, whereby those who rarely use a particular charging scheme do not have the necessary in-vehicle equipment to pay the charges automatically. ANPR is a variation on the automatic account identification system, which also relies on the vehicle's number plate as its unique identifier.

A Government Office for London Report (Government Office for London, 2000) reviewed the road-use charging options for London (the "ROCOL" report) in 1998/1999. It studied the feasibility of road-use pricing and work-place parking charging, as well as the likely impacts on business, traffic levels and users' reactions to the charging proposals. It recommended that London should implement a video-based road-use charging system, in the first instance, until the results of the Department for Transport's DIRECTS project become available. One compelling argument for the use of ANPR is that there is no need for drivers to fit equipment in the vehicle to facilitate the charge. It all relies on the driver registering his vehicle licence plate with the charging authority in advance of the trip (and pay the appropriate charge) - for those that miss this pre-trip registration, London offers the facility to post-register and pay up to $10 \mathrm{pm}$ on the evening of the day that the trip took place. In August 2002 the Mayor, Ken Livingstone, gave the final go-ahead to proceed towards a full-scale implementation of congestion charging in central London, using ANPR. The highly publicised launch of London was on the $17^{\text {th }}$ February 2003 - and it seems to work. There are clearly some technical problems with the scheme but the management of it seems sufficiently robust to cope. Indeed 18 months on the reduction in traffic is still around $15-18 \%$ and the difference in the environment and travel-times within the Cordon is remarkable (Transport for London, 2004). This has led to a rethink by many local authorities as to their options for charging.

\section{How congestion charging systems may evolve}

The three competing families of technology for future charging systems have different attributes, advantages and disadvantages. For many years, DSRC-based systems have been preferred, due to their simplicity of operation, potential for supporting additional services for vehicle users and, most importantly, because they are easy for users to understand you pass a point and you pay. New technologies, however, have opened up new opportunities for innovative charging schemes. Wide area charging schemes are attractive and offer new possibilities for charging without the main disadvantage of short-range charging systems, namely the associated road-side infrastructure at every charging and enforcement point. Some infrastructure is still required for enforcement purposes, but this 
can be situated in locations where aesthetics are not a prime consideration. Portable and mobile enforcement systems are also possible (Egeler and Bibaritsch, 2003). Effective operation and enforcement using GPS-based systems was demonstrated in the previously mentioned Hong Kong charging trials (1998-99). Moreover, the distance-based taxation of heavy goods vehicles which is currently being procured by the UK Customs and Excise (HM Customs and Excise, 2004) could probably only be efficiently implemented using some form of wide area charging (probably linked to vehicles' digital tachographs - as in Switzerland). Video-based charging is a very recent innovation, with London being the first large urban area to adopt such an approach. In Norway, ANPR/video is used as the primary charging means in the cities of Kristiansand and Bergen: however, this is on a very small scale in comparison with London. For central London, the scheme has clearly required a very complex back-office clearing and management system, to register on a daily basis all those who wish to pay to use the charged area within the cordon and also to record and process the images of all vehicles recorded, entering the charged area - but who have not registered and paid. If the system in London continues to be deemed a success over the next two or three years, several other UK cities, including Edinburgh, may introduce a similar system although the question of increasing the scale of a central London cordon into a much larger scheme using the same technology package is as of yet not answered. Indeed London is currently running an extensive series of trails to look at possible future technologies for any extension to the London Scheme.

Looking ahead, the short-term future evolution of charging is likely to be a fusion of DSRC with either an ANPR or wide-area charging systems - which will be able to support several different charging configurations with one set of in-vehicle equipment. However recent trials of wide area technologies (GPS and cellular phones) in the urban environment of London have been less than conclusive. Whilst the city of Stockholm has decided to use a DSRC technology to provide a charging cordon around the city by end of 2005 and to facilitate interoperability with some of the toll bridges, such as Øresund, which already operates DSRC toll-technology.

\section{Summary of charging projects and plans in the UK}

\subsection{Operational projects}

Durham. First cordon toll was introduced in a UK urban area, in October 2002. A $£ 2.00$ charge is levied from drivers wishing to use the cul-de-sac road leading to the Cathedral/Castle peninsula in Durham City (figure 2). The aim was to reduce traffic to the historic centre of the city - a possible model for other small historical cities - and it has been successful in that aim, with traffic reportedly down $90 \%$. 


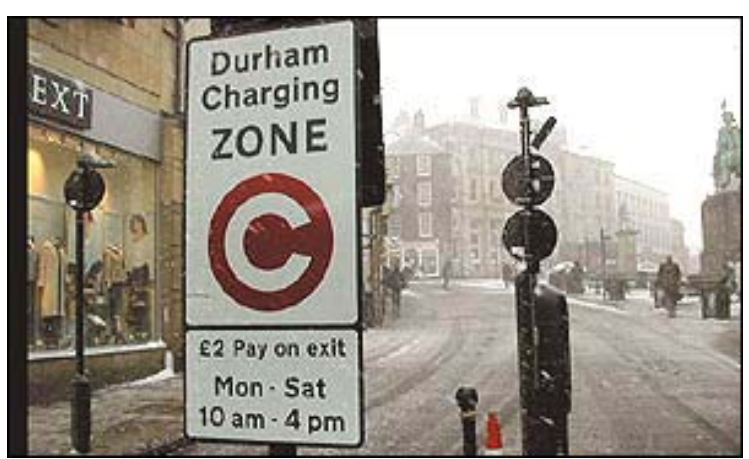

Figure 2: Durham congestion charging scheme

Central London. The Congestion Charging Scheme within a cordon around Central London went live in February 2003 (figure $3 \mathrm{a}$ and $3 \mathrm{~b}$ ) and has up to now been regarded as successful in terms of reducing traffic volumes by between 15 and 20\% (Transport for London, 2004) and the relatively high levels of acceptance by the public and local businesses. However the scheme has not been as successful in delivering the anticipated revenue for reinvestment in London's transport infrastructure - which was initially estimated as $£ 120 \mathrm{M}$ per annum but in reality for $2003-04$ was closer to $£ 80 \mathrm{M}$. This shortfall is in part due to greater the expected reductions in traffic and the higher operational costs associated with the manually-intensive process of call-centre registrations of licence plates and the follow-up activities related to the enforcement, and penalty notices processes (Murray-Clarke, 2004).

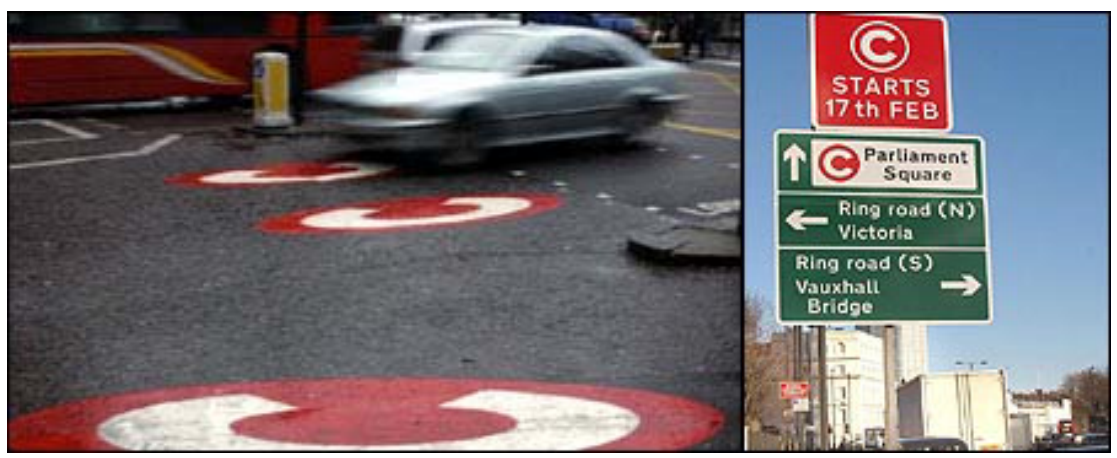

Figures 3a: Entering the London charging zone. 3b charging information signs

The newly re-elected mayor, Ken Livingstone, plans to extend the boundaries of the cordon westwards (to include Kensington and Chelsea). A new scheme order is likely in 2004. Trials of technology to assess their suitability for extensions or upgrades to the congestion zone are also currently underway (Evans, 2004).

DIRECTS (field-trials), Leeds.

The national demonstration of road-use charging technical interoperability will be hosted by Leeds City Council. The Fareway Consortium was selected and awarded the contract in 2001 by the Department for Transport. Following extensive acceptance trials throughout 2003/4 the actual on-road trial of interoperability between equipment from different manufacturers will finally get underway in early 2005 . The results of the project will be a 
full Technical Specification for congestion charging, using DSRC and MSP equipment, to be available in 2006 .

\subsection{Other congestion charging projects being planned}

Edinburgh. This is the most advanced of the other schemes. Edinburgh City Council has completed a large-scale public participation exercise, inviting people living within Edinburgh and a wide area surrounding the city to choose between three options. A bare majority (51\% for, with 38\% against) voted for a single cordon-charging scheme around the central area. A minority (44\% for, with $45 \%$ against) voted for a double cordon scheme. Lastly, a minority (38\% for, with $43 \%$ against) voted for not introducing any congestion charging scheme at all. The proposed scheme involves two separate cordons of inbound, point based, charging points. The inner cordon coincides approximately with the World Heritage Site boundary and the outer cordon inside the Edinburgh Bypass. A single daily $£ 2.00$ charge is proposed for Monday to Friday.

Bristol. Bristol has participated in a number of trials of Road Use Charging, including the PROGESS project (Smith and Murphy, 2004). A cordon around the city centre has been studied, plus distance-based charging on adjacent motorways. But there are no dates for introduction of a real scheme.

West Midlands. Possible charging scheme is being developed for the central Birmingham and Solihull areas and is already under discussion.

\subsection{Nationwide charging plans for the UK}

Heavy Goods Vehicle Charging. The Chancellor confirmed plans for distance-based Heavy Goods Vehicle charging in his April 2002 budget and has the backing of the Freight Transport Association (FTA) and of the CBI. The current procurement timetables issued by Customs and Excise suggest the HGV charging will be introduced in the UK in 2008 (HM Customs and Excise, 2004). This follows similar moves elsewhere in Europe, USA and New Zealand.

National Charging Scheme. In the background, however, there is the feeling that the real agenda is to examine the feasibility of how quickly such a scheme can be "rolled out" to include cars and other vehicles using our congested motorways. The Commission for Integrated Transport see this as the logical corollary to developing congestion charging in the urban "hot spots" (Commission for Integrated Transport, 2002). A National Steering Committee was established in 2003 by the Secretary of State to examine this issue. They published their recommendations on the $21^{\text {st }}$ July 2004 which suggested that a National Charging Scheme which would replace current fixed vehicle excise duty and to some extent fuel tax will be introduced in around 2014 when suitable MPS technology exists for the whole vehicle fleet in the UK (namely a sub-meter accurate positioning system sufficiently reliable and cheap to be fitted to the entire UK vehicle fleet). 


\section{Summary: A confused message?}

The concern one has is that there are now three parallel tracks of road use charging in the UK: The local authority led Congestion Charging, The Treasury and Customs-led Heavy Goods Vehicles Charging, and the Department for Transport-led National Charging scheme. Is this likely to send out confused and mixed messages to drivers? Will they be able to distinguish between which is a local hypothecated charge (the former) and which are national tax-raising measures (the latter two). In addition tolling of infrastructure such as the M6 Toll Road adds further murkiness to the debate.

To accept one form of charging - as has been demonstrated in London - is an achievement. To gain the buy-in of the general public and business to three different road use charges is unlikely - particularly in the UK where the likelihood that the charges will instantly reflect in a better road and general transport system is optimistic, to say the least. Nevertheless the emergence of a potential new generation of mobile technologies to meet the future demands of widespread charging offer another unprecedented opportunity for the UK to remain at the forefront of future congestion charging research as well as leading the way with a range of innovative implementations of road user charging schemes.

\section{$9 \quad$ References}

Balmer, U. (2003) "Demand Management by User Charging - The Swiss Experience," Proc. $10^{\text {th }}$ World Congress on Intelligent Transport Systems and Services, November, Madrid.

Birle, C. (2004) "Use of GSM and 3G Cellular Radio for Electronic Fee Collection. IEE Seminar on Road User Charging," 9 June 2004, London. www.iee.org/oncomms/pn/auto.

Blythe, P. T. and A. Pickford (2004) "Where do we go from here?" IEE Seminar on Road User Charging, 9 June, London. www.iee.org/oncomms/pn/auto.

Blythe, P. T. (1998) Electronic Tolling in Europe: State of the Art and Future Trends. Operation and Maintenance of Large Infrastructure Projects. Operation and Maintenance of Large Infrastructure Projects, Balkema.

Blythe, P. T. and P. J. Hills (1994) "Automatic Toll Collection and the Pricing of RoadSpace," in Advanced Technology for Road Transport. London: Artech House.

Blythe, P. T, P. Knight, and J. Walker (2001) "Is it Feasible for Automatic Number-Plate Recognition Systems to be used as the Primary Means for Road-User Charging?" Proceeding of ITS-UK Annual Summer Conference, July, Cardiff.

Blythe, P. T. (2003) "Road User Charging in the UK. Will We Ever See an Emergence of Technical and Political Consensus?" Proc. 10 ${ }^{\text {th }}$ World Congress on Intelligent Transport Systems and Services, November, Madrid.

Buchanan, M. (1963) The Buchanan Report, Traffic in Towns. UK Ministry of Transport, HMSO, London. 
Charpentier, G and G. Fremont. (2003) "The ETC System for HGV on Highways in Germany: First Lessons after System Opening," Proc. 10 ${ }^{\text {th }}$ World Congress on Intelligent Transport Systems and Services, November, Madrid.

Commission for Integrated Transport (2002) "Paying for Road Use," CfIT Report, HMSO, London, February. http://www.cfit.gov.uk/reports/pfru/index.htm.

Department for Transport (1998) A New Deal for Transport. White Paper, UK Ministry of Transport, HMSO, London.

Department for Transport (2003) Transport Statistics: Great Britain. UK Ministry of Transport, HMSO, London.

Egeler, C. and M. Bibaritsch. (2003) "Enforcement of the Austrian Heavy Goods Vehicle Toll," Proc. $10^{\text {th }}$ World Congress on Intelligent Transport Systems and Services, November, Madrid.

Evans, J (2004) "Update on London's Congestion Charging System," IEE Seminar on Road User Charging, March, London.

Government Office for London (2000) "Road Charging Options for London," The Stationery Office, London. http://www.go-london.gov.uk/localregionalgov/rocol.htm.

Hills, P. J. and P. T. Blythe (1989) “Paying Your Way,” IEE Review, 35: 377-381.

Hills, P. J. and P. T. Blythe (1990) "Road Pricing: Solving the Technical Problems," Journal of Economic Affairs, 8-10.

HM Customs and Excise (2004) "Lorry Road User Charging Progress Reports," http://www.hmce.gov.uk.

HM Treasury (2001) "Revolutionising the Taxation of the Haulage Industry," $h t t p: / / w w w . h m-$ treasury.gov.uk/consultations_and_legislation/haulage/consult_haulage_index.cfm

Kossak A. (2004) "Tolling Heavy Goods Vehicles on Germany's Autobahns," IEE Seminar on Road User Charging, 9 June, London. http://www.iee.org/oncomms/pn/auto.

Mackinnon, D (2003) “The DfT Road User Charging Research On-Road Programme,” IEE Seminar on Road User Charging, March, London.

Murray-Clarke, M. (2004) "The London Congestion Charging Scheme" Proc. $11^{\text {th }}$ World Congress on Intelligent Transport Systems and Services, October, Nagoya, Japan.

Pigou, A. C. (1920) The Economics of Welfare. London: Macmillan.

Ruidisch P. (2003) "The Toll System for HGV in Germany - One of the Most Modern Systems in the World," Proc. $10^{\text {th }}$ World Congress on Intelligent Transport Systems and Services, November, Madrid. 
Smeed, R (1964) The Smeed Report, Road Pricing: The Economic and Technical Possibilities. UK Ministry of Transport, HMSO, London.

Smith, L. and T. Murphy (2004) "Bristol City Case Study: PRoGR€SS MPS Trial," IEE Seminar on Road User Charging, 9 June, London. http://www.iee.org/oncomms/pn/auto.

Times (2003) "Minister Announces Research into a National Road Charging Scheme," The Times, 10 July, London.

Tindall, D.W. (2004) "Road User Charging Demonstration Project," IEE Seminar on Road User Charging, 9 June, London. http://www.iee.org/oncomms/pn/auto.

Transport for London (2004) "Congestion Charging: Update on Scheme Impacts and Operations," February, Transport for London. http://www.tfl.gov.uk.

Vickrey, W. S. (1969) "Congestion Theory and Transport Investment," American Economic Review, 59: 251-260.

Walters, A. A. (1961) "The Theory and Measurement of Private and Social Cost of Highway Congestion," Econometrica, 29: 676-697. 